\title{
Highly sensitive Lens culinaris agglutinin-reactive fraction of $\alpha$-fetoprotein is a predictive marker for hepatocarcinogenesis in long-term observation of patients with chronic liver disease
}

\author{
KAZUAKI TABU, SEIICHI MAWATARI, KOHEI ODA, OHKI TANIYAMA, AI TOYODOME, SHO IJUIN, \\ HARUKA SAKAE, KOTARO KUMAGAI, SHUJI KANMURA and AKIO IDO

\begin{abstract}
Digestive and Lifestyle Diseases, Department of Human and Environmental Sciences, Kagoshima
University Graduate School of Medical and Dental Sciences, Kagoshima 890-8544, Japan
\end{abstract}

Received April 13, 2020; Accepted June 3, 2021

DOI: $10.3892 / \mathrm{mco} .2021 .2336$

\begin{abstract}
Highly sensitive Lens culinaris agglutinin-reactive fraction of $\alpha$-fetoprotein (hs-AFP-L3) is a specific marker for hepatocellular carcinoma (HCC) and has been reliable in cases with a low serum $\alpha$-fetoprotein (AFP) level. However, the biomarkers that contribute to hepatocarcinogenesis during the long-term observation are not yet clear. The present study reported the clinical utility of hs-AFP-L3 in the long-term observation of patients with chronic liver disease. The subjects were 106 patients with chronic liver disease without HCC or a history of HCC treatment and who had been followed for $>12$ months. hs-AFP-L3 was measured using cryopreserved serum. The factors contributing to hepatocarcinogenesis were examined using univariate and multivariate analyses. The median observation period was 88 months (15-132 months). The cumulative incidence of $\mathrm{HCC}$ was $10.5 \%$ at 5 years and $19.6 \%$ at 10 years. The univariate analysis revealed that age $\geq 55$ years old, platelet count $\leq 13.1 \times 10^{4} / \mu 1$, hyaluronic acid $\geq 80.8 \mathrm{ng} / \mathrm{ml}$, alanine transaminase $\geq 47 \mathrm{U} / \mathrm{l}$, AFP $\geq 6.3 \mathrm{ng} / \mathrm{ml}$, hs-AFP-L3 $\geq 3.5 \%$ and des- $\gamma$-carboxy prothrombin (DCP) $\geq 25 \mathrm{mAU} / \mathrm{ml}$ were significant factors. In the multivariate analysis, platelet count $\leq 13.1 \times 10^{4} / \mu 1$ [hazard ratio (HR), 4.966; 95\% confidence interval (CI), 1.597-15.437; P=0.006] and hs-AFP-L3 $\geq 3.5 \%$ (HR, 5.450; 95\% CI, 1.522-19.512; $\mathrm{P}=0.009)$ were extracted as significant factors contributing to hepatocarcinogenesis. In addition, for cases with AFP $<20 \mathrm{ng} / \mathrm{ml}$, a multivariate analysis revealed that hs-AFP-L3 $\geq 4.9 \%$ (HR, 11.608; 95\% CI, 2.422-55.629; $\mathrm{P}=0.002)$ and $\mathrm{DCP} \geq 25 \mathrm{mAU} / \mathrm{ml}$ (HR, 3.936; 95\% CI, 1.088-14.231; $\mathrm{P}=0.037)$ were significant factors contributing
\end{abstract}

Correspondence to: Dr Seiichi Mawatari, Digestive and Lifestyle Diseases, Department of Human and Environmental Sciences, Kagoshima University Graduate School of Medical and Dental Sciences, 8-35-1 Sakuragaoka, Kagoshima 890-8544, Japan E-mail: mawatari@m2.kufm.kagoshima-u.ac.jp

Key words: $\alpha$-fetoprotein, hepatocellular carcinoma, highly sensitive Lens culinaris agglutinin-reactive fraction of $\alpha$-fetoprotein, hepatocarcinogenesis, chronic liver disease to hepatocarcinogenesis. hs-AFP-L3 is a useful marker for predicting hepatocarcinogenesis in the long-term observation of patients with chronic liver disease.

\section{Introduction}

Liver cancer is the sixth-most commonly diagnosed cancer and the fourth leading cause of cancer death worldwide (1). Hepatocellular carcinoma (HCC) accounts for $90 \%$ of primary liver cancers, and hepatitis $\mathrm{B}$ virus (HBV) and hepatitis $\mathrm{C}$ virus (HCV) infection as well as alcohol consumption and non-alcoholic steatohepatitis (NASH) are known risk factors (2-4).

The early detection of HCC by regular surveillance may lead to curative treatment and improve the prognosis (5). Several methods developed for the diagnosis of HCC, including the evaluation of serum markers, ultrasonography (US), computed tomography (CT), and magnetic resonance imaging (MRI), have been tested clinically. Among these methods, US is simple with a low invasiveness, but its accuracy depends on the skill of the examiner. Contrast-enhanced CT and MRI are useful for the diagnosis but are invasive. The most widely used markers are $\alpha$-fetoprotein (AFP) and des- $\gamma$ carboxy prothrombin (DCP), serum proteins that are elevated in HCC. Although routine screening offers the best chance for early tumor detection, the reported sensitivities and specificities of elevated serum AFP and DCP levels vary significantly (6-12).

In 2009, the highly sensitive Lens culinaris agglutininreactive fraction of AFP (hs-AFP-L3) assay was developed, and AFP-L3 measurement became possible, even in cases with AFP $<20 \mathrm{ng} / \mathrm{ml}$ (13). However, biomarkers that contribute to hepatocarcinogenesis during the long-term observation of patients with chronic liver disease are still unclear. We previously examined the clinical utility of hs-AFP-L3 in patients with chronic liver disease (9). Seven years have passed since that study, so we examined the clinical utility of hs-AFP-L3 in a long-term observation.

\section{Materials and methods}

Study population. Frozen serum samples were collected from 117 patients with chronic liver disease without HCC who visited 
our hospital between December 1, 2006, and March 31, 2011. The analysis was performed on 106 patients, excluding those who had been treated for HCC, those who had been under observation for less than 12 months, and those who were taking warfarin tablets (Fig. 1). In most patients with chronic hepatitis, liver imaging with US was performed every 6 to 12 months, and in patients with cirrhosis, CT, MRI, or US was performed every 3 to 6 months. The definitive diagnosis of HCC that occurred during follow-up was made by interventional radiology CT (IVR-CT). HBV was defined as Hepatitis B surface antigen (HBsAg) positivity. $\mathrm{HCV}$ was defined as anti-HCV antibody positivity.

Measurement of serum AFP and hs-AFP-L3. AFP and hs-AFP-L3 levels were measured using the cryopreserved serum. Hs-AFP-L3 was measured by microchip capillary electrophoresis and a liquid-phase binding assay on a $\mu$-TASWako i30 automatic analyzer (Wako Pure Chemical Industries, Ltd.) (13). When hs-AFP-L3 was not detectable, the percentage of hs-AFP-L3 was defined as $0 \%$.

Statistical analysis. First, we considered the correlation between the hs-AFP-L3 level and other clinical data. In addition, the presence of HCC as of March 31,2018, was confirmed, and the ability to predict hepatocarcinogenesis using liver tumor markers was compared using a receiver operating characteristic (ROC) curve. Finally, we investigated the factors contributing to hepatocarcinogenesis using univariate and multivariate analyses. The cut-off value was set to an optimal value using the Youden index (sensitivity + specificity-1) (14).

Statistical analyses were performed using the SPSS statistical software program, version 25 (IBM Corp.). Categorical data were compared using the chi-squared test and Fisher's exact test, as appropriate. Continuous variables were analyzed using the Mann-Whitney U test. The correlation coefficient was tested using Spearman's rank correlation coefficient or Pearson's correlation coefficient. The Kaplan-Meier method was used to estimate cumulative incidence rate of HCC, and its distribution curves were compared using the log-rank test. P-values of $<0.05$ were considered to indicate statistical significance. Factors contributing to hepatocarcinogenesis were determined using Cox's proportional hazards model with forward selection using $\mathrm{P}<0.10$ as a cut-off for inclusion in the model.

\section{Results}

Clinical feature of patients. The clinical characteristics of the population analyzed are shown (Table I). The causes of chronic liver disease were HBV in 23 cases, HCV in 60 cases, and non-HBV and non-HCV in 23 cases, of which 17 were liver cirrhosis. The median observation period was 88 months (15-132 months). The AFP value in the analysis subject population was $27.1 \pm 119.3 \mathrm{ng} / \mathrm{ml}$, and the hs-AFP-L3 value was $2.9 \pm 5.3 \%$.

Correlation between $h s-A F P-L 3$ and clinical data. We confirmed the correlation between hs-AFP-L3 and other clinical data. Hs-AFP-L3 showed a positive correlation with the age, alanine transaminase (ALT), hyaluronic acid, and AFP and a negative correlation with the platelet count and albumin (Table IIA). In a study of 90 patients with AFP
Table I. Clinical features of patients with benign liver disease $(n=106)$.

\begin{tabular}{|c|c|}
\hline Variable & Value \\
\hline Age $^{\mathrm{a}}$, years & $57.5(11-82)$ \\
\hline Sex (male/female), $\mathrm{n}$ & $38 / 68$ \\
\hline $\mathrm{CH} / \mathrm{LC}, \mathrm{n}$ & $89 / 17$ \\
\hline Etiology (HBV/HCV/NBNC), n & $23 / 60 / 23$ \\
\hline Child-Pugh class (A/B/C/unknown), $n$ & $83 / 3 / 2 / 18$ \\
\hline $\mathrm{AFP}^{\mathrm{b}}, \mathrm{ng} / \mathrm{ml}$ & $27.1 \pm 119.3$ \\
\hline hs-AFP-L3 ${ }^{\mathrm{b}}, \%$ & $2.9 \pm 5.3$ \\
\hline $\mathrm{DCP}^{\mathrm{b}}, \mathrm{mAU} / \mathrm{ml}$ & $18 \pm 8$ \\
\hline Platelet count ${ }^{\mathrm{b}}, \times 10^{4} / \mu 1$ & $16.4 \pm 7.2$ \\
\hline $\mathrm{ALT}^{\mathrm{b}}, \mathrm{U} / 1$ & $79 \pm 121$ \\
\hline Total bilirubin $^{\mathrm{b}}, \mathrm{mg} / \mathrm{dl}$ & $1.0 \pm 0.6$ \\
\hline Albumin $^{\mathrm{b}}, \mathrm{g} / \mathrm{dl}$ & $4.2 \pm 0.5$ \\
\hline Hyaluronic acid ${ }^{\mathrm{b}}, \mathrm{ng} / \mathrm{ml}$ & $175.7 \pm 444.6$ \\
\hline Observation period ${ }^{\mathrm{a}}$, months & $88(15-132)$ \\
\hline
\end{tabular}

${ }^{\mathrm{a}}$ Median (min-max). ${ }^{\mathrm{b}}$ Mean $\pm \mathrm{SD} . \mathrm{CH}$, chronic hepatitis; LC, liver cirrhosis; $\mathrm{HBV}$, hepatitis $\mathrm{B}$ virus; $\mathrm{HCV}$, hepatitis $\mathrm{C}$ virus; NBNC, HBV(-) and HCV(-); AFP, $\alpha$-fetoprotein; hs-AFP-L3, highly sensitive Lens culinaris agglutinin-reactive fraction of AFP; DCP, des- $\gamma$-carboxy prothrombin; ALT, alanine transaminase.

$<20 \mathrm{ng} / \mathrm{ml}$, hs-AFP-L3 showed a positive correlation with the age, hyaluronic acid, and AFP and a negative correlation with the platelet count (Table IIB).

Cumulative incidence of HCC. The presence of HCC as of March 31, 2018, was confirmed, and 17 out of 106 patients (16.0\%) were found to have developed HCC. Cumulative incidence of HCC development was $10.5 \%$ at 5 years and $19.6 \%$ at 10 years (Fig. 2). The clinical characteristics of hepatocarcinogenesis cases are shown in Tables III and IV. In the background comparison between the non-carcinogenic group and the carcinogenic group, the age $(\mathrm{P}=0.009)$, AFP $(\mathrm{P}<0.001)$, hs-AFP-L3 $(\mathrm{P}<0.001)$, platelet count $(\mathrm{P}<0.001)$, ALT $(\mathrm{P}=0.018)$, albumin $(\mathrm{P}=0.023)$, and hyaluronic acid $(\mathrm{P}<0.001)$ differed significantly (Table IV).

Predictive ability for hepatocarcinogenesis. On comparing the predictive ability for hepatocarcinogenesis using an ROC curve, the cut-off value of hs-AFP-L3 was $3.5 \%$, and the sensitivity, specificity, and the area under the ROC curve (AUC) were 82.4, 73.0\%, and 0.800, respectively. Similarly, the cut-off value of AFP was $6.3 \mathrm{ng} / \mathrm{ml}$, and the sensitivity, specificity, and AUC were 82.4, 75.3\%, and 0.833, respectively. The cut-off value of DCP was $25 \mathrm{mAU} / \mathrm{ml}$, and the sensitivity, specificity, and AUC were 35.3, 93.3\%, and 0.507, respectively (Fig. 3A). The ability of hs-AFP-L3 and AFP to predict HCC development was higher than that of DCP. In the analysis of 90 patients with AFP $<20 \mathrm{ng} / \mathrm{ml}$, the cut-off value of hs-AFP-L3 was $4.9 \%$, and the sensitivity, specificity, and AUC were 80.0, 85.0\%, and 0.812, respectively. Similarly, the cut-off value of AFP was $4.6 \mathrm{ng} / \mathrm{ml}$, and the 
Table II. Association between highly sensitive Lens culinaris agglutinin-reactive fraction of AFP and clinical data.

A, Correlation with highly sensitive Lens culinaris agglutinin-reactive fraction of AFP $(\mathrm{n}=106)$

\begin{tabular}{lccccccccc}
\hline Variable & Age $^{\mathrm{a}}$ & ALT $^{\mathrm{a}}$ & Hyaluronic acid $^{\mathrm{a}}$ & AFP $^{\mathrm{a}}$ & DCP $^{\mathrm{a}}$ & Plt $^{\mathrm{b}}$ & Albumin $^{\mathrm{a}}$ & T-Bil $^{\mathrm{a}}$ \\
\hline Correlation coefficient & 0.232 & 0.262 & 0.479 & 0.724 & -0.080 & -0.256 & -0.354 & 0.163 \\
P-value & 0.017 & 0.007 & $<0.001$ & $<0.001$ & 0.418 & 0.008 & $<0.001$ & 0.096 \\
$\mathrm{n}$ & 106 & 106 & 106 & 106 & 106 & 106 & 101 & 105 \\
\hline
\end{tabular}

B, Correlation with highly sensitive Lens culinaris agglutinin-reactive fraction of AFP ( $\mathrm{n}=90 ; \mathrm{AFP}<20 \mathrm{ng} / \mathrm{ml})$

\begin{tabular}{lccccccrr}
\hline Variable & Age $^{\mathrm{a}}$ & ALT $^{\mathrm{a}}$ & Hyaluronic acid & AFP $^{\mathrm{a}}$ & DCP $^{\mathrm{a}}$ & Plt $^{\mathrm{b}}$ & Albumin $^{\mathrm{a}}$ & T-Bil $^{\mathrm{a}}$ \\
\hline Correlation coefficient & 0.269 & 0.164 & 0.352 & 0.666 & -0.159 & -0.282 & -0.211 & -0.011 \\
P-value & 0.010 & 0.123 & 0.001 & $<0.001$ & 0.134 & 0.007 & 0.052 & 0.922 \\
$\mathrm{n}$ & 90 & 90 & 90 & 90 & 90 & 90 & 85 & 89 \\
\hline
\end{tabular}

${ }^{a}$ Spearman's rank correlation coefficient. ${ }^{b}$ Pearson's correlation coefficient. AFP, $\alpha$-fetoprotein; ALT, alanine transaminase; DCP, des- $\gamma$-carboxy prothrombin; Plt, platelet count; T-Bil, total bilirubin.

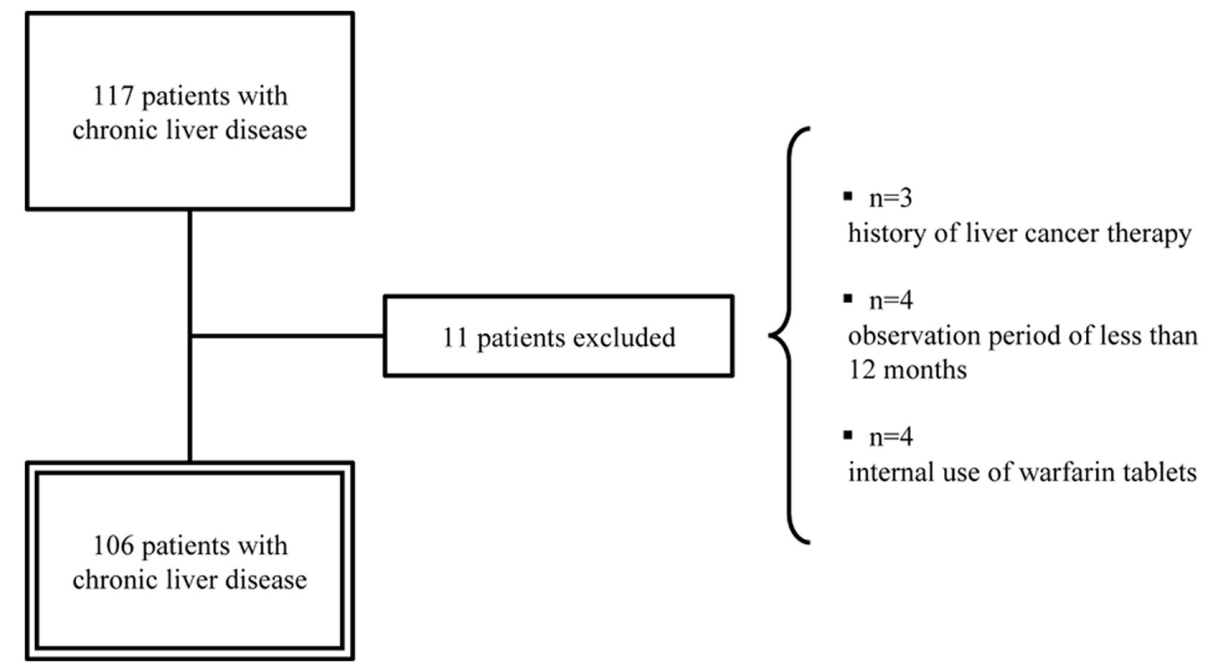

Figure 1. Schematic representation of the patient selection process.

sensitivity, specificity, and AUC were 80.0, 75.0\%, and 0.844, respectively. The cut-off value of DCP was $25 \mathrm{mAU} / \mathrm{ml}$, and the sensitivity, specificity, and AUC were $40.0 \%, 95.0 \%$, and 0.616, respectively (Fig. 3B). In patients with AFP $<20 \mathrm{ng} / \mathrm{ml}$, the ability of hs-AFP-L3 and AFP to predict HCC development was higher than that of DCP.

Factors contributing to hepatocarcinogenesis. An examination of the factors contributing to hepatocarcinogenesis according to a univariate analysis showed that age $\geq 55$ years old $(\mathrm{P}=0.016)$, platelet count $\leq 13.1 \times 10^{4} / \mu 1(\mathrm{P}=0.001)$, hyaluronic acid $\geq 80.8 \mathrm{ng} / \mathrm{ml}(\mathrm{P}<0.001)$, ALT $\geq 47 \mathrm{U} / \mathrm{l}(\mathrm{P}=0.008)$, AFP $\geq 6.3 \mathrm{ng} / \mathrm{ml}(\mathrm{P}<0.001)$, hs-AFP-L3 $\geq 3.5 \%(\mathrm{P}<0.001)$, $\mathrm{DCP} \geq 25 \mathrm{mAU} / \mathrm{ml}(\mathrm{P}=0.002)$ were significant factors. In the multivariate analysis, the platelet count $\leq 13.1 \times 10^{4} / \mu 1$ (hazard ratio $[\mathrm{HR}]=4.966,95 \%$ confidence interval $[\mathrm{CI}]$ 1.597-15.437, $\mathrm{P}=0.006)$ and hs-AFP-L3 $\geq 3.5 \%(\mathrm{HR}=5.450,95 \% \mathrm{CI}$
1.522-19.512, $\mathrm{P}=0.009)$ were extracted as significant factors contributing to hepatocarcinogenesis (Table V). In addition, in patients with AFP $<20 \mathrm{ng} / \mathrm{ml}$, the univariate analysis showed that age $\geq 64$ years old $(\mathrm{P}=0.005)$, liver cirrhosis $(\mathrm{P}=0.047)$, platelet count $\leq 13.1 \times 10^{4} / \mu 1(\mathrm{P}=0.002)$, hyaluronic acid $\geq 67.7 \mathrm{ng} / \mathrm{ml}(\mathrm{P}=0.010)$, ALT $\geq 47 \mathrm{U} / 1 \quad \mathrm{P}=0.037)$, AFP $\geq 4.6 \mathrm{ng} / \mathrm{ml}(\mathrm{P}=0.002)$, hs-AFP-L3 $\geq 4.9 \%$ ( $<<0.001)$, DCP $\geq 25 \mathrm{mAU} / \mathrm{ml}(\mathrm{P}=0.003)$ were significant factors. In the multivariate analysis, hs-AFP-L3 $\geq 4.9 \%(\mathrm{HR}=11.608,95 \% \mathrm{CI}$ 2.422-55.629, $\mathrm{P}=0.002)$ and $\mathrm{DCP} \geq 25 \mathrm{mAU} / \mathrm{ml}(\mathrm{HR}=3.936$, 95\% CI 1.088-14.231, $\mathrm{P}=0.037)$ were extracted as significant factors contributing to hepatocarcinogenesis (Table VI).

Comparison of cumulative incidence of HCC by hs-AFP-L3. The cumulative incidence of HCC was significantly higher in patients with hs-AFP-L3 $\geq 3.5 \%$ than in those with hs-AFP-L3 $<3.5 \%$ (24.7\% at 5 years, $40.0 \%$ at 10 years vs. $1.6 \%$ at 5 years, 
Table V. Factors contributing to hepatocarcinogenesis $(n=106)$.

\begin{tabular}{|c|c|c|c|c|}
\hline \multirow[b]{2}{*}{ Variable } & \multirow{2}{*}{$\frac{\begin{array}{c}\text { Univariate } \\
\text { analysis }^{\mathrm{a}}\end{array}}{\text { P-value }}$} & \multicolumn{3}{|c|}{ Multivariate analysis ${ }^{\mathrm{b}}$} \\
\hline & & Hazard ratio & $95 \% \mathrm{CI}$ & P-value \\
\hline Age ( $<55$ vs. $\geq 55$ years $)$ & 0.016 & & & \\
\hline Sex (female vs. male) & 0.978 & & & \\
\hline Background liver (CH vs. LC) & 0.128 & & & \\
\hline Total bilirubin $(<0.6 \mathrm{vs} . \geq 0.6 \mathrm{mg} / \mathrm{dl})$ & 0.212 & & & \\
\hline Albumin $(>4.4 \mathrm{vs} . \leq 4.4 \mathrm{~g} / \mathrm{dl})$ & 0.113 & & & \\
\hline Platelet count $\left(>13.1\right.$ vs. $\left.\leq 13.1 \times 10^{4} / \mu 1\right)$ & 0.001 & 4.966 & $1.597-15.437$ & 0.006 \\
\hline Hyaluronic acid (<80.8 vs. $\geq 80.8 \mathrm{ng} / \mathrm{ml})$ & $<0.001$ & & & \\
\hline $\operatorname{ALT}(<47$ vs. $\geq 47 \mathrm{U} / \mathrm{l})$ & 0.008 & 3.019 & $0.841-10.836$ & 0.090 \\
\hline $\operatorname{AFP}(<6.3 \mathrm{vs} . \geq 6.3 \mathrm{ng} / \mathrm{ml})$ & $<0.001$ & & & \\
\hline hs-AFP-L3 (<3.5 vs. $\geq 3.5 \%)$ & $<0.001$ & 5.450 & $1.522-19.512$ & 0.009 \\
\hline $\mathrm{DCP}(<25 \mathrm{vs} . \geq 25 \mathrm{mAU} / \mathrm{ml})$ & 0.002 & & & \\
\hline
\end{tabular}

${ }^{a}$ Log-rank test. ${ }^{\mathrm{b}}$ Cox proportional hazards model. ALT, alanine transaminase; AFP, $\alpha$-fetoprotein; hs-AFP-L3, highly sensitive Lens culinaris agglutinin-reactive fraction of AFP; DCP, des- $\gamma$-carboxy prothrombin; $\mathrm{CH}$, chronic hepatitis; $\mathrm{LC}$, liver cirrhosis; $\mathrm{CI}$, confidence interval.

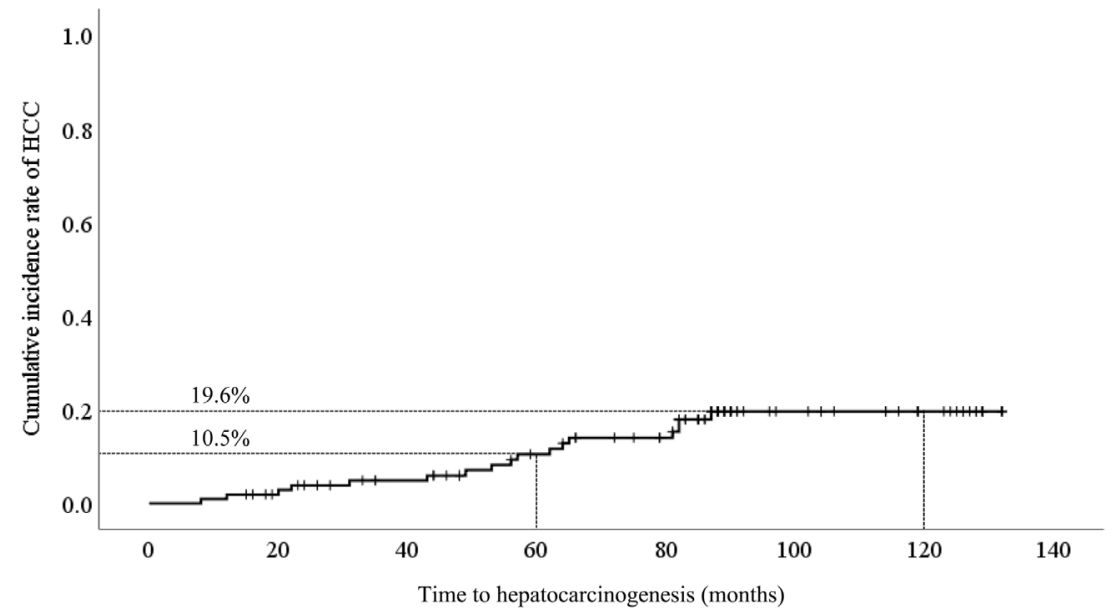

Figure 2. Cumulative incidence rate of HCC in the present study population ( $\mathrm{n}=106)$. HCC, hepatocellular carcinoma.

A

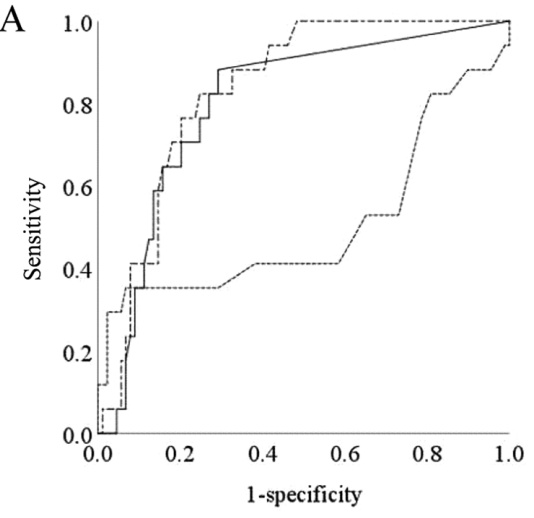

$\begin{array}{lcccc} & \text { Cut-off } & \text { Sensitivity } & \text { Specificity } & \text { AUC } \\ \text { hs-AFP-L3 } & 3.5 \% & 82.4 \% & 73.0 \% & 0.800 \\ \text { AFP } & 6.3 \mathrm{ng} / \mathrm{ml} & 82.4 \% & 75.3 \% & 0.833 \\ \text { DCP } & 25 \mathrm{mAU} / \mathrm{ml} & 35.3 \% & 93.3 \% & 0.507\end{array}$

B
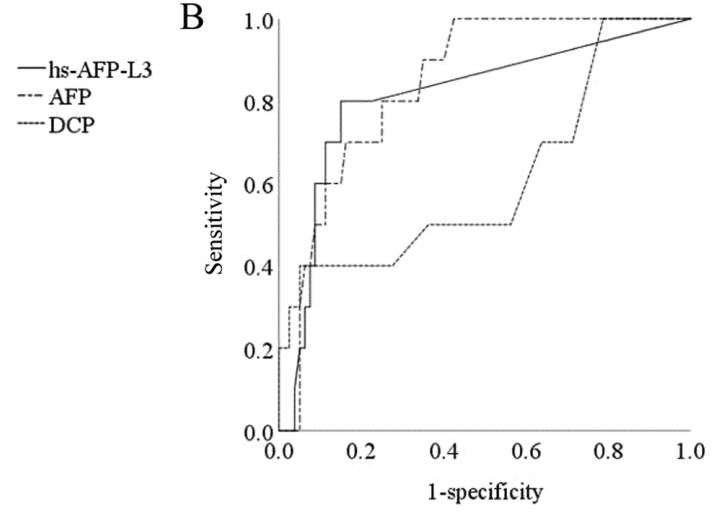

$\begin{array}{lcccc} & \text { Cut-off } & \text { Sensitivity } & \text { Specificity } & \text { AUC } \\ \text { hs-AFP-L3 } & 4.9 \% & 80.0 \% & 85.0 \% & 0.812 \\ \text { AFP } & 4.6 \mathrm{ng} / \mathrm{ml} & 80.0 \% & 75.0 \% & 0.844 \\ \text { DCP } & 25 \mathrm{mAU} / \mathrm{ml} & 40.0 \% & 95.0 \% & 0.616\end{array}$

Figure 3. Comparison of the predictive ability for hepatocarcinogenesis using an ROC curve. (A) ROC curve of hs-AFP-L3, AFP and DCP in the analysis target population ( $\mathrm{n}=106)$. (B) ROC curve of hs-AFP-L3, AFP and DCP in patients with AFP $<20 \mathrm{ng} / \mathrm{ml}$ ( $\mathrm{n}=90)$. ROC, receiver operating characteristic; AFP, $\alpha$-fetoprotein; hs-AFP-L3, highly sensitive Lens culinaris agglutinin-reactive fraction of AFP; DCP, des- $\gamma$ carboxy prothrombin; AUC, area under the curve. 
Table III. Characterization of 17 patients with benign liver disease who developed HCC.

\begin{tabular}{|c|c|c|c|c|c|c|c|c|c|}
\hline Case no. & Age, years & Sex & $\mathrm{CH} / \mathrm{LC}$ & Etiology & $\begin{array}{l}\text { AFP, } \\
\mathrm{ng} / \mathrm{ml}\end{array}$ & hs-AFP-L3, \% & $\begin{array}{c}\mathrm{DCP} \\
\mathrm{mAU} / \mathrm{ml}\end{array}$ & ALT, U/1 & $\begin{array}{l}\text { Months until } \\
\text { HCC detection }\end{array}$ \\
\hline 1 & 60 & Male & $\mathrm{LC}$ & $\mathrm{HCV}$ & 28.5 & 9.6 & 32 & 65 & 8 \\
\hline 2 & 70 & Female & $\mathrm{LC}$ & NBNC & 10.9 & 8.4 & 15 & 39 & 12 \\
\hline 3 & 65 & Female & $\mathrm{CH}$ & $\mathrm{HCV}$ & 3.3 & $<0.5$ & 26 & 82 & 20 \\
\hline 4 & 69 & Male & $\mathrm{CH}$ & $\mathrm{HCV}$ & 4.7 & 6.4 & 13 & 52 & 22 \\
\hline 5 & 70 & Female & $\mathrm{CH}$ & $\mathrm{HCV}$ & 8.3 & 7.0 & 15 & 48 & 31 \\
\hline 6 & 56 & Female & $\mathrm{CH}$ & $\mathrm{HCV}$ & 46.9 & 4.5 & 5 & 98 & 43 \\
\hline 7 & 73 & Female & $\mathrm{CH}$ & $\mathrm{HCV}$ & 11.4 & 7.3 & 12 & 54 & 49 \\
\hline 8 & 59 & Female & $\mathrm{CH}$ & $\mathrm{HCV}$ & 32.0 & 3.7 & 13 & 116 & 53 \\
\hline 9 & 52 & Male & $\mathrm{CH}$ & $\mathrm{HBV}$ & 23.6 & 7.1 & 10 & 489 & 56 \\
\hline 10 & 73 & Female & $\mathrm{LC}$ & $\mathrm{HCV}$ & 9.6 & 6.6 & 13 & 71 & 57 \\
\hline 11 & 70 & Female & $\mathrm{CH}$ & $\mathrm{HBV}$ & 24.3 & 8.4 & 13 & 30 & 62 \\
\hline 12 & 53 & Male & $\mathrm{CH}$ & $\mathrm{HCV}$ & 6.4 & 5.2 & 29 & 145 & 64 \\
\hline 13 & 66 & Female & $\mathrm{CH}$ & $\mathrm{HCV}$ & 10.0 & 5.8 & 19 & 122 & 65 \\
\hline 14 & 57 & Female & $\mathrm{CH}$ & $\mathrm{HCV}$ & 7.8 & 7.9 & 45 & 52 & 81 \\
\hline 15 & 53 & Male & $\mathrm{LC}$ & NBNC & 3.7 & $<0.5$ & 53 & 22 & 82 \\
\hline 16 & 62 & Male & $\mathrm{CH}$ & $\mathrm{HCV}$ & 23.0 & 7.5 & 35 & 72 & 82 \\
\hline 17 & 66 & Female & $\mathrm{CH}$ & $\mathrm{HCV}$ & 576.0 & 3.1 & 8 & 126 & 87 \\
\hline
\end{tabular}

HCC, hepatocellular carcinoma; $\mathrm{CH}$, chronic hepatitis; LC, liver cirrhosis; HBV, hepatitis B virus; HCV, hepatitis C virus; NBNC, HBV(-) and HCV(-); AFP, $\alpha$-fetoprotein; hs-AFP-L3, highly sensitive Lens culinaris agglutinin-reactive fraction of AFP; DCP, des- $\gamma$-carboxy prothrombin; ALT, alanine transaminase.

Table IV. Clinical features of patients in the non-carcinogenic and carcinogenic groups.

\begin{tabular}{|c|c|c|c|}
\hline Variable & Non-carcinogenic group $(n=89)$ & Carcinogenic group $(n=17)$ & P-value \\
\hline Age $^{\mathrm{a}}$, years & $54 \pm 15$ & $63 \pm 7$ & $0.009^{\mathrm{b}}$ \\
\hline Sex (male/female), $\mathrm{n}$ & $32 / 57$ & $6 / 11$ & $0.958^{\mathrm{c}}$ \\
\hline $\mathrm{CH} / \mathrm{LC}, \mathrm{n}$ & $76 / 13$ & $13 / 4$ & $0.468^{\mathrm{d}}$ \\
\hline Etiology (HBV/HCV/NBNC), n & $21 / 47 / 21$ & $2 / 13 / 2$ & $0.197^{\mathrm{c}}$ \\
\hline Child-Pugh class (A/B/C/unknown), n & $68 / 2 / 2 / 17$ & $15 / 1 / 0 / 1$ & $0.428^{\mathrm{c}}$ \\
\hline $\mathrm{AFP}^{\mathrm{a}}, \mathrm{ng} / \mathrm{ml}$ & $22.9 \pm 116.1$ & $48.8 \pm 136.4$ & $<0.001^{\mathrm{b}}$ \\
\hline hs-AFP-L3 ${ }^{\mathrm{a}}, \%$ & $2.4 \pm 5.5$ & $5.8 \pm 2.8$ & $<0.001^{\mathrm{b}}$ \\
\hline $\mathrm{DCP}^{\mathrm{a}}, \mathrm{mAU} / \mathrm{ml}$ & $17 \pm 6$ & $21 \pm 14$ & $0.928^{\mathrm{b}}$ \\
\hline Platelet count ${ }^{\mathrm{a}}, \times 10^{4} / \mu 1$ & $17.5 \pm 7.1$ & $10.7 \pm 4.9$ & $<0.001^{\mathrm{b}}$ \\
\hline $\mathrm{ALT}^{\mathrm{a}}, \mathrm{U} / 1$ & $75 \pm 123$ & $99 \pm 107$ & $0.018^{\mathrm{b}}$ \\
\hline Total bilirubin ${ }^{\mathrm{a}}, \mathrm{mg} / \mathrm{dl}$ & $1.0 \pm 0.6$ & $0.9 \pm 0.4$ & $0.585^{\mathrm{b}}$ \\
\hline Albumin $^{\mathrm{a}}, \mathrm{g} / \mathrm{dl}$ & $4.2 \pm 0.5$ & $4.0 \pm 0.5$ & $0.023^{\mathrm{b}}$ \\
\hline Hyaluronic acid ${ }^{\mathrm{a}}, \mathrm{ng} / \mathrm{ml}$ & $172.6 \pm 483.2$ & $191.6 \pm 110.9$ & $<0.001^{\mathrm{b}}$ \\
\hline Observation period $^{\mathrm{a}}$, months & $84 \pm 32$ & $98 \pm 18$ & $0.060^{\mathrm{b}}$ \\
\hline
\end{tabular}

${ }^{\mathrm{a}}$ Mean \pm SD. ${ }^{\mathrm{b}}$ Mann-Whitney U test. $\chi^{\mathrm{c}} \chi^{2}$ test. ${ }^{\mathrm{d}}$ Fisher's exact test. $\mathrm{CH}$, chronic hepatitis; LC, liver cirrhosis; HBV, hepatitis B virus; HCV, hepatitis C virus; NBNC, HBV(-) and HCV(-); AFP, $\alpha$-fetoprotein; hs-AFP-L3, highly sensitive Lens culinaris agglutinin-reactive fraction of AFP; DCP, des- $\gamma$-carboxy prothrombin; ALT, alanine transaminase.

$6.8 \%$ at 10 years, $\mathrm{P}<0.001$ ) (Fig. $4 \mathrm{~A})$. In addition, in cases of AFP $<20 \mathrm{ng} / \mathrm{ml}$, the cumulative incidence of HCC was significantly higher in patients with hs-AFP-L3 $\geq 4.9 \%$ than in those with hs-AFP-L3 $<4.9 \%$ (24.6\% at 5 years, $39.7 \%$ at 10 years vs. $1.5 \%$ at 5 years, $3.6 \%$ at 10 years, $\mathrm{P}<0.001$ ) (Fig. $4 \mathrm{~B}$ ).

\section{Discussion}

Recent advances in imaging technology have enabled the early detection of HCC (15-17), so low AFP cases often result in a diagnosis of hepatocarcinogenesis. In the present study, it was found 
Table VI. Factors contributing to hepatocarcinogenesis ( $\mathrm{n}=90 ;$ AFP $<20 \mathrm{ng} / \mathrm{ml}$ ).

\begin{tabular}{|c|c|c|c|c|}
\hline \multirow[b]{2}{*}{ Variable } & \multirow{2}{*}{$\frac{\begin{array}{c}\text { Univariate } \\
\text { analysis }^{\mathrm{a}}\end{array}}{\text { P-value }}$} & \multicolumn{3}{|c|}{ Multivariate analysis ${ }^{\mathrm{b}}$} \\
\hline & & Hazard ratio & $95 \% \mathrm{CI}$ & P-value \\
\hline Age ( $<64$ vs. $\geq 64$ years $)$ & 0.005 & & & \\
\hline Sex (female vs. male) & 0.844 & & & \\
\hline Background liver (CH vs. LC) & 0.047 & & & \\
\hline Total bilirubin $(<1.2 \mathrm{vs} . \geq 1.2 \mathrm{mg} / \mathrm{dl})$ & 0.218 & & & \\
\hline Albumin $(>4.4$ vs. $\leq 4.4 \mathrm{~g} / \mathrm{dl})$ & 0.119 & & & \\
\hline Platelet count $\left(>13.1\right.$ vs. $\left.\leq 13.1 \times 10^{4} / \mu 1\right)$ & 0.002 & & & \\
\hline Hyaluronic acid (<67.7 vs. $\geq 67.7 \mathrm{ng} / \mathrm{ml})$ & 0.010 & & & \\
\hline $\operatorname{ALT}(<47$ vs. $\geq 47 \mathrm{U} / \mathrm{l})$ & 0.037 & & & \\
\hline $\operatorname{AFP}(<4.6 \mathrm{vs} . \geq 4.6 \mathrm{ng} / \mathrm{ml})$ & 0.002 & & & \\
\hline hs-AFP-L3 (<4.9 vs. $\geq 4.9 \%)$ & $<0.001$ & 11.608 & $2.422-55.629$ & 0.002 \\
\hline $\mathrm{DCP}(<25 \mathrm{vs} . \geq 25 \mathrm{mAU} / \mathrm{ml})$ & 0.003 & 3.936 & $1.088-14.231$ & 0.037 \\
\hline
\end{tabular}

${ }^{a}$ Log-rank test. ${ }^{\mathrm{b}}$ Cox proportional hazards model. ALT, alanine transaminase; AFP, $\alpha$-fetoprotein; hs-AFP-L3, highly sensitive Lens culinaris agglutinin-reactive fraction of AFP; DCP, des- $\gamma$-carboxy prothrombin; $\mathrm{CH}$, chronic hepatitis; LC, liver cirrhosis; CI, confidence interval.
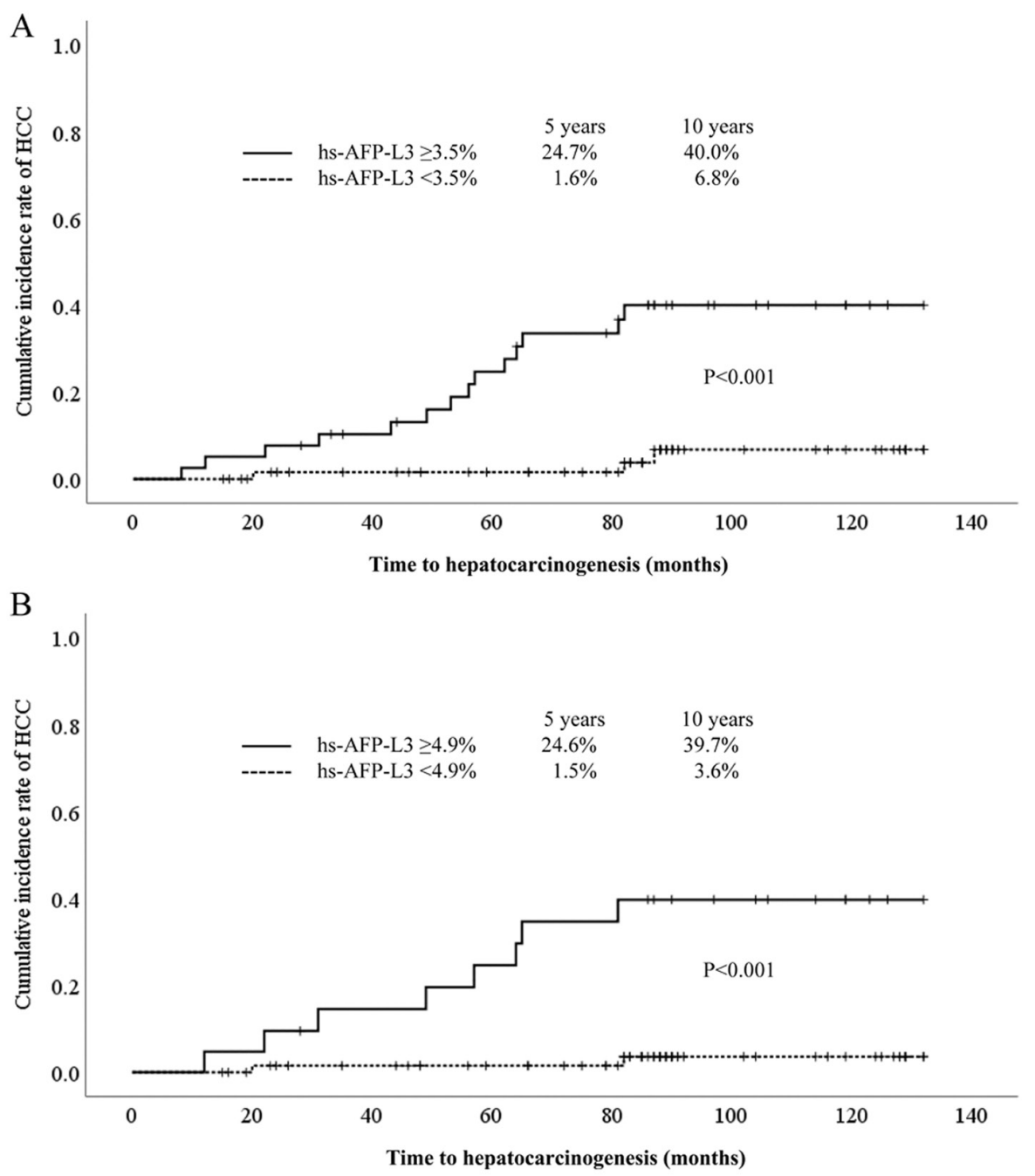

Figure 4. Comparison of the cumulative incidence rate of HCC by hs-AFP-L3. (A) In the analysis target population (n=106), the cumulative incidence of HCC was significantly higher in patients with hs-AFP-L3 $\geq 3.5 \%$ than in those with hs-AFP-L3 $<3.5 \%$ (log-rank test P<0.001). (B) In patients with AFP $<20 \mathrm{ng} / \mathrm{ml}$ $(\mathrm{n}=90)$, the cumulative incidence of HCC was significantly higher in patients with hs-AFP-L3 $\geq 4.9 \%$ than in those with hs-AFP-L3 $<4.9 \%$ (log-rank test $\mathrm{P}<0.001)$. HCC, hepatocellular carcinoma; AFP, $\alpha$-fetoprotein; hs-AFP-L3, highly sensitive Lens culinaris agglutinin-reactive fraction of AFP. 
that 10 of 17 patients with AFP $<20 \mathrm{ng} / \mathrm{ml}(58.8 \%)$ had hepatocarcinogenic on long-term follow-up. In our previous study, we found that hs-AFP-L3 was a useful marker for predicting hepatocarcinogenesis, but the observation period averaged 32.8 months, and the examination was made by a univariate analysis (9). In the present study, after a long-term observation, we performed a multivariate analysis of factors associated with the development of HCC and revealed that hs-AFP-L3 was the best predictive marker for hepatocarcinogenesis. It was found to be particularly useful in cases with AFP $<20 \mathrm{ng} / \mathrm{ml}$.

AFP is a glycoprotein with a molecular weight of $67 \mathrm{kDa}$ that was first reported in human fetal serum by Bergstrand and Czar (18) in 1956. AFP is elevated in patients with HCC but also in the active phases of chronic hepatitis and cirrhosis as well as in AFP-producing tumors other than liver cancer (19). The sugar chains of AFP differ depending on the producing cell, and the L3 fraction is specific for HCC in terms of its affinity for lentil lectin (20-24). However, measurement of AFP-L3 has not always been reliable for serum samples with a low total AFP concentration, as determined by conventional lectin affinity system (LiBASys) (25). The highly sensitive AFP-L3 measurement method uses an on-chip electrokinetic reaction and separation by affinity electrophoresis (micro-total analysis system; $\mu$-TAS) (26). This system has enabled the accurate measurement of AFP-L3 at very low AFP concentrations.

In a previous report on the prediction of hepatocarcinogenesis, Kumada et al (22) conducted a study of 104 patients with hepatocarcinogenesis and 104 controls matched by propensity scores in HCC surveillance involving 2,830 patients with chronic liver disease. One year before the diagnosis of HCC, the cut-off value of hs-AFP-L3 was 7\%, and the sensitivity and specificity were 34.3 and $74.7 \%$, respectively. Similarly, with cut-off values of AFP $20 \mathrm{ng} / \mathrm{ml}$ and DCP $40 \mathrm{mAU} / \mathrm{ml}$, the respective sensitivity was 35.0 and $12.1 \%$, and the respective specificity was 86.4 and $93.9 \%$ (22). In the present study, the best cut-off values of hs-AFP-L3, AFP, and DCP for predicting $\mathrm{HCC}$ were $3.5 \%, 6.3 \mathrm{ng} / \mathrm{ml}$, and $25 \mathrm{mAU} / \mathrm{ml}$, respectively, with respective sensitivities of $82.4,82.4$ and $35.3 \%$ and respective specificities of 73.0, 75.3, and 93.3\%. Similarly, in patients with AFP $<20 \mathrm{ng} / \mathrm{ml}$, the best cut-off values of hs-AFP-L3, AFP, and DCP were $4.9 \%, 4.6 \mathrm{ng} / \mathrm{ml}$ and $25 \mathrm{mAU} / \mathrm{ml}$, respective, with respective sensitivities of $80.0,80.0$ and $40.0 \%$ and respective specificities of $85.0,75.0$ and $95.0 \%$. In this way, our findings differed from those of previous reports. This discrepancy is attributed to differences in the study design, as the previous report used stored sera collected annually for three years before the diagnosis of HCC. In addition, the median observation period in our study was 88 months (15 to 132 months), which was longer than in the previous study.

In this study, 11 out of 17 cases of hepatocarcinogenesis developed HCC more than 4 years after the test, and 9 out of 11 cases $(81.8 \%)$ had hs-AFP-L3 $\geq 3.5 \%$. The doubling time of HCC is reported to be 100 days, and it theoretically takes about 9 years for a $10-\mu \mathrm{m} \mathrm{HCC}$ to become a $10-\mathrm{mm}$ lesion, which can be detected by diagnostic imaging (27). In other words, the involvement of hs-AFP-L3 in hepatocarcinogenesis several years later may indicate the presence of minute HCC.

However, in hepatitis $\mathrm{C}$ patients treated with interferon, the hepatocarcinogenesis rate decreases after achieving a sustained virologic response (SVR), and AFP values after antiviral therapy are known to be independent predictors of hepatocarcinogenesis $(28,29)$. In addition, it has been reported that serum Wisteria floribunda agglutinin positive Mac-2 binding protein $\left(\mathrm{WFA}^{+} \mathrm{M} 2 \mathrm{BP}\right)$, a liver fibrosis marker that has recently been clinically applied, becomes a risk factor for hepatocarcinogenesis after achieving an SVR of hepatitis C $(30,31)$. Direct-acting antivirals (DAAs) have been developed for HCV, and virus elimination by DAA reportedly suppresses hepatocarcinogenesis $(32,33)$. The usefulness of measuring the hs-AFP-L3 value before and after DAA therapy is unclear at present and needs to be clarified in the future.

The study is limited by its retrospective nature and the small number of cases.

In conclusion, hs-AFP-L3 is a useful marker for predicting hepatocarcinogenesis in the long-term observation of patients with chronic liver disease.

\section{Acknowledgements}

The authors would like to thank Ms. Hiromi Eguchi, Ms. Yuko Nakamura and Ms. Eriko Koreeda (all Digestive and Lifestyle Diseases, Department of Human and Environmental Sciences, Kagoshima University Graduate School of Medical and Dental Sciences, Kagoshima, Japan) for their technical assistance and data management.

\section{Funding}

No funding was received.

\section{Availability of data and materials}

The datasets used and/or analyzed during the current study are available from the corresponding author on reasonable request.

\section{Authors' contributions}

KT, SM, KO, KK and AI conceived the study. KT, SM, KO, OT, AT, SI, HS, KK and SK contributed the acquisition of data. KT and SM confirm the authenticity of all the raw data. KT and SM analyzed the data and prepared the manuscript. KT, SM and AI reviewed the manuscript. KT, SM, KO, OT, AT, SI, HS, $\mathrm{KK}, \mathrm{SK}$ and AI have been involved in revising the manuscript critically for important intellectual content and agreed to be accountable for all aspects of the work. All authors read and approved the final manuscript.

\section{Ethics approval and consent to participate}

The study protocol conformed to the ethical guidelines of the Declaration of Helsinki and was approved by the Kagoshima University Ethics Committee on Epidemiological Studies (approval no. 180162; Kagoshima, Japan). Written informed consent was obtained from all patients for the use of stored serum samples.

\section{Patient consent for publication}

Not applicable. 


\section{Competing interests}

The authors declare that they have no competing interests.

\section{References}

1. Bray F, Ferlay J, Soerjomataram I, Siegel RL, Torre LA and Jemal A: Global cancer statistics 2018: GLOBOCAN estimates of incidence and mortality worldwide for 36 cancers in 185 countries CA Cancer J Clin 68: 394-424, 2018

2. European Association For The Study Of The Liver; European Organisation For Research And Treatment Of Cancer: EASL-EORTC clinical practice guidelines: Management of hepatocellular carcinoma. J Hepatol 56: 908-943, 2012.

3. Global Burden of Disease Liver Cancer Collaboration, Akinyemiju T, Abera S, Ahmed M, Alam N, Alemayohu MA, Allen C, Al-Raddadi R, Alvis-Guzman N, Amoako Y, et al: The burden of primary liver cancer and underlying etiologies from 1990 to 2015 at the global, regional, and national level: Results from the global burden of disease study 2015. JAMA Oncol 3: 1683-1691, 2017.

4. Llovet JM, Zucman-Rossi J, Pikarsky E, Sangro B, Schwartz M, Sherman M and Gores G: Hepatocellular carcinoma. Nat Rev Dis Primers 2: 16018, 2016.

5. Zhang BH, Yang BH and Tang ZY: Randomized controlled trial of screening for hepatocellular carcinoma. J Cancer Res Clin Oncol 130: 417-422, 2004.

6. Grazi GL, Mazziotti A, Legnani C, Jovine E, Miniero R, Gallucci A, Palareti G and Gozzetti G: The role of tumor markers in the diagnosis of hepatocellular carcinoma, with special reference to the des-gamma-carboxy prothrombin. Liver Transpl Surg 1: 249-255, 1995

7. Ishii M, Gama H, Chida N, Ueno Y, Shinzawa H, Takagi T, Toyota T, Takahashi T and Kasukawa R: Simultaneous measurements of serum alpha-fetoprotein and protein induced by vitamin $\mathrm{K}$ absence for detecting hepatocellular carcinoma. South Tohoku District study group. Am J Gastroenterol 95: 1036-1040, 2000

8. Marrero JA, Su GL, Wei W, Emick D, Conjeevaram HS, Fontana RJ and Lok AS: Des-gamma carboxyprothrombin can differentiate hepatocellular carcinoma from nonmalignant chronic liver disease in american patients. Hepatology 37: 1114-1121, 2003.

9. Oda K, Ido A, Tamai T, Matsushita M, Kumagai K, Mawatari S, Saishoji A, Kure T, Ohno K, Toyokura E, et al: Highly sensitive Lens culinaris agglutinin-reactive $\alpha$-fetoprotein is useful for early detection of hepatocellular carcinoma in patients with chronic liver disease. Oncol Rep 26: 1227-1233, 2011.

10. Oka H, Tamori A, Kuroki T, Kobayashi K and Yamamoto S: Prospective study of alpha-fetoprotein in cirrhotic patients monitored for development of hepatocellular carcinoma. Hepatology 19: 61-66, 1994.

11. Okuda H, Nakanishi T, Takatsu K, Saito A, Hayashi N, Takasaki K, Takenami K, Yamamoto M and Nakano M: Serum levels of des-gamma-carboxy prothrombin measured using the revised enzyme immunoassay kit with increased sensitivity in relation to clinicopathologic features of solitary hepatocellular carcinoma Cancer 88: 544-549, 2000

12. Wang CS, Lin CL, Lee HC, Chen KY, Chiang MF, Chen HS, Lin TJ and Liao LY: Usefulness of serum des-gamma-carboxy prothrombin in detection of hepatocellular carcinoma. World $\mathbf{J}$ Gastroenterol 11: 6115-6119,2005.

13. Kagebayashi C, Yamaguchi I, Akinaga A, Kitano H, Yokoyama K, Satomura M, Kurosawa T, Watanabe M, Kawabata T, Chang W, et al: Automated immunoassay system for AFP-L3\% using on-chip electrokinetic reaction and separation by affinity electrophoresis. Anal Biochem 388: 306-311, 2009.

14. Youden WJ: Index for rating diagnostic tests. Cancer 3: 32-35, 1950.

15. Kierans AS, Kang SK and Rosenkrantz AB: The diagnostic performance of dynamic contrast-enhanced MR imaging for detection of small hepatocellular carcinoma measuring Up to $2 \mathrm{~cm}$ : A meta-analysis. Radiology 278: 82-94, 2016.

16. Onishi H, Kim T, Imai Y, Hori M, Nagano H, Nakaya Y, Tsuboyama T, Nakamoto A, Tatsumi M, Kumano S, et al: Hypervascular hepatocellular carcinomas: Detection with gadoxetate disodium-enhanced MR imaging and multiphasic multidetector CT. Eur Radiol 22: 845-854, 2012.
17. Sangiovanni A, Manini MA, Iavarone M, Romeo R, Forzenigo LV, Fraquelli M, Massironi S, Della Corte C, Ronchi G, Rumi MG, et al: The diagnostic and economic impact of contrast imaging techniques in the diagnosis of small hepatocellular carcinoma in cirrhosis. Gut 59: 638-644, 2010.

18. Bergstrand CG and Czar B: Demonstration of a new protein fraction in serum from the human fetus. Scand J Clin Lab Invest 8: 174, 1956.

19. Taketa K: Alpha-fetoprotein: Reevaluation in hepatology. Hepatology 12: 1420-1432, 1990.

20. Aoyagi Y, Isemura M, Suzuki Y, Sekine C, Soga K, Ozaki T and Ichida F: Fucosylated alpha-fetoprotein as marker of early hepatocellular carcinoma. Lancet 2: 1353-1354, 1985.

21. Korekane H, Hasegawa T, Matsumoto A, Kinoshita N, Miyoshi E and Taniguchi N: Development of an antibody-lectin enzyme immunoassay for fucosylated alpha-fetoprotein. Biochim Biophys Acta 1820: 1405-1411, 2012.

22. Kumada $\mathrm{T}$, Toyoda $\mathrm{H}$, Tada $\mathrm{T}$, Kiriyama S, Tanikawa M, Hisanaga Y, Kanamori A, Tanaka J, Kagebayashi C and Satomura S: High-sensitivity Lens culinaris agglutinin-reactive alpha-fetoprotein assay predicts early detection of hepatocellular carcinoma. J Gastroenterol 49: 555-563, 2014.

23. Oka H, Saito A, Ito K, Kumada T, Satomura S, Kasugai H, Osaki Y, Seki T, Kudo M and Tanaka M; Collaborative Hepato-Oncology Study Group of Japan: Multicenter prospective analysis of newly diagnosed hepatocellular carcinoma with respect to the percentage of Lens culinaris agglutinin-reactive alpha-fetoprotein. J Gastroenterol Hepatol 16: 1378-1383, 2001.

24. Taketa K, Sekiya C, Namiki M, Akamatsu K, Ohta Y, Endo Y and Kosaka K: Lectin-reactive profiles of alpha-fetoprotein characterizing hepatocellular carcinoma and related conditions. Gastroenterology 99: 508-518, 1990.

25. Nakamura K, Imajo N, Yamagata Y, Katoh H, Fujio K, Tanaka T, Satomura S and Matsuura S: Liquid-phase binding assay of alpha-fetoprotein using a sulfated antibody for bound/free separation. Anal Chem 70: 954-957, 1998.

26. Kawabata T, Wada HG, Watanabe $M$ and Satomura S: Electrokinetic analyte transport assay for alpha-fetoprotein immunoassay integrates mixing, reaction and separation on-chip. Electrophoresis 29: 1399-1406, 2008.

27. Cucchetti A, Garuti F, Pinna AD and Trevisani F; Italian Liver Cancer (ITA.LI.CA) group: Length time bias in surveillance for hepatocellular carcinoma and how to avoid it. Hepatol Res 46: 1275-1280, 2016

28. Hiramatsu N, Oze T and Takehara T: Suppression of hepatocellular carcinoma development in hepatitis $C$ patients given interferon-based antiviral therapy. Hepatol Res 45: 152-161, 2015.

29. Oze T, Hiramatsu N, Yakushijin T, Miyazaki M, Yamada A, Oshita M,Hagiwara H, Mita E, Ito T, Fukui H, et al: Post-treatment levels of $\alpha$-fetoprotein predict incidence of hepatocellular carcinoma after interferon therapy. Clin Gastroenterol Hepatol 12: 1186-1195, 2014

30. Nagata H, Nakagawa M, Asahina Y, Sato A, Asano Y, Tsunoda T, Miyoshi M, Kaneko S, Otani S, Kawai-Kitahata F, et al: Effect of interferon-based and -free therapy on early occurrence and recurrence of hepatocellular carcinoma in chronic hepatitis $C$. J Hepatol 67: 933-939, 2017.

31. Sasaki R, Yamasaki K, Abiru S, Komori A, Nagaoka S, Saeki A, Hashimoto S, Bekki S, Kugiyama Y, Kuno A, et al: Serum Wisteria floribunda agglutinin-positive Mac-2 binding protein values predict the development of hepatocellular carcinoma among patients with chronic hepatitis $\mathrm{C}$ after sustained virological response. PLoS One 10: $\mathrm{e}$ 0129053, 2015.

32. Ioannou GN, Green PK and Berry K: HCV eradication induced by direct-acting antiviral agents reduces the risk of hepatocellular carcinoma. J Hepatol 68: 25-32, 2018.

33. Kanwal F, Kramer J, Asch SM, Chayanupatkul M, Cao Y and El-Serag HB: Risk of hepatocellular cancer in HCV patients treated with direct-acting antiviral agents. Gastroenterology 153 : 996-1005.e1, 2017.

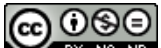

This work is licensed under a Creative Commons Attribution-NonCommercial-NoDerivatives 4.0 International (CC BY-NC-ND 4.0) License. 